${ }^{1}$ SubDepartamento de Medicina, Hospital Base de Valdivia. Valdivia, Chile. Instituto de Medicina, Facultad de Medicina, Campus Isla Teja, Universidad Austral de Chile. Valdivia, Chile. ${ }^{3}$ Unidad de Atención y Control en Salud Sexual (UNACESS), Hospital Base de Valdivia. Valdivia, Chile.

${ }^{4}$ Unidad de Epidemiología y Registro Hospitalario del Cáncer, Hospital Base de Valdivia. Valdivia, Chile.

aTecnólogo Médico bInterno, Carrera de Medicina. Facultad de Medicina, Campus Isla Teja, Universidad Austral de Chile. Valdivia, Chile. 'Matrona.

Trabajo no recibió financiamiento. Los autores declaran no tener conflictos de interés.

Recibido el 4 de octubre de 2020, aceptado el 18 de enero de 2021.

Correspondencia a: Dr. Alberto Fica SubDepartamento de Medicina, Hospital Base de Valdivia. Bueras 1003. Valdivia, Chile. albertoficacubillos@gmail.com

\section{The resurgence of syphilis among pregnant women in southern Chile}

\author{
ALBERTO FICA $^{1,2}$, PAMELA MONTIEL ${ }^{3, \mathrm{c}}$, SOFÍA SAAVEDRA $^{\mathrm{b}}$, \\ MATÍAS MEISSNER ${ }^{\mathrm{b}}$, JUAN CARLOS VELÁSQUEZ,
}

\begin{abstract}
Background: National rates of HIV, gonorrhoeae and syphilis have increased in Chile in recent years, but it is not known if syphilis among pregnant women $(P W)$ is also escalating. Aim: To explore syphilis rates among PW in a southern Chilean region and to describe clinical features of mothers and offspring. Patients and Methods: We selected $P W$ with positive VDRL or T. pallidum micro-hemagglutination (MHA-TP) reactive tests, referred to a high-risk obstetrical pathology center between 2011 and 2019. Clinical information of mothers and their offspring was obtained from their medical records. Results: Syphilis rates among PW increased from 0.4 to 7.2 per 1,000 live births in the reference center from 2013 to 2019, along with a national and regional increase in both sexes. Twenty-nine cases of $P W$ with syphilis were identified with a median age of 28 years (interquartile range 23-32). Seventeen percent had a history of drug abuse, and $14 \%$ had previous sexually transmitted diseases. In seven cases (24\%), the diagnosis occurred at delivery. Three percent of patients had a primary syphilis, $14 \%$ a secondary syphilis, $24 \%$ an early latent syphilis, and $59 \%$ a latent syphilis. All cases except one case were treated with benzathine penicillin $G$ and the remaining with erythromycin due to allergy suspicion. Penicillin desensitization was required in two cases (7\%). Treatment timing was inadequate in 10 cases (34.5\%). Of 19 patients with available serological follow-up, 10 (53\%) showed a significant decrease in VDRL titers ( $\geq 2$ dilutions) and two cases had re-infection. Two patients (7\%) had an abortion, two had congenital syphilis (7\%), and six had premature births (21\%), totaling 35\% of adverse-pregnancy outcomes. Conclusions: Resurgence of syphilis among pregnant women is happening in southern Chile and is associated to adverse-pregnancy outcomes.
\end{abstract}

(Rev Med Chile 2021; 149: 348-356)

Key words: Pregnancy; Premature Birth; Syphilis; Syphilis, Congenital; Syphilis Serodiagnosis.

\section{Resurgencia de sífilis en mujeres embarazadas en una región del sur de Chile}

Antecedentes: Las tasas nacionales de VIH, gonorrea y sifilis han aumentado en Chile en los últimos años, pero no se sabe si la sífilis en mujeres embarazadas (ME) también está aumentando. Objetivo: Explorar las tasas de sifilis en ME en una región del sur de Chile y describir las características clínicas de las madres y los hijos. Pacientes y Métodos: Se seleccionaron ME con un VDRL o test de microhemaglutinación para T. pallidum positivos, referidas a 
un centro de alto riesgo obstétrico entre 2011 y 2019. La información clínica de las madres y sus hijos fue obtenida de fichas clinicas. Resultados: Las tasas de sifilis en ME aumentaron de 0,4 a 7,2 por 1000 nacidos vivos en el hospital de referencia entre 2013 y 2019, en paralelo a un aumento nacional y regional en ambos sexos. Se identificaron 29 casos de mujeres embarazadas con sifilis con mediana de edad 28 años, rango intercuartílico 23-32. Diecisiete por ciento tenía historia de abuso de drogas y $14 \%$ tenía una enfermedad de transmisión sexual previa. En siete casos, el diagnóstico ocurrió en el momento del parto (24,1\%). Los estadios abarcaron sifilis primaria (3\%), sifilis secundaria (14\%), sifilis latente temprana (24\%) y sifilis latente (59\%). Todos, menos un caso, fueron tratados con penicilina $G$ benzatina y el caso restante con eritromicina por sospecha de alergia a la penicilina. Se requirieron protocolos de desensibilización a penicilina en dos casos (7\%). El momento del tratamiento fue inadecuado en 10 casos (35\%). De 19 pacientes con seguimiento serológico disponible, 10 (53\%) mostraron una disminución significativa en los títulos de VDRL ( $\geq 2$ diluciones) y dos casos tuvieron reinfección. Dos pacientes (7\%) evolucionaron con aborto, dos con sífilis congénita (7\%, una asociada a terapia con macrólidos) y seis con parto prematuro o bajo peso al nacer (21\%), totalizando 35\% de resultados adversos durante el embarazo. Conclusiones: El resurgimiento de la sifilis entre las mujeres embarazadas está ocurriendo en el sur de Chile y está asociado a resultados adversos del embarazo.

Palabras clave: Sifilis; Embarazo; Pruebas Serológicas; Sífilis Congénita; Nacimiento Prematuro.

S ince the beginning of the 21 st century, syphilis has re-emerged in different parts of the world, initially in populations of men who have sex with men (MSM) and later among heterosexual men and women ${ }^{1-3}$. Syphilis in women is associated with the risk of vertical transmission during pregnancy with severe consequences such as miscarriages, stillbirths, premature births, low birth weight infants, congenital syphilis (CS) and infant mortality ${ }^{3}$. By 2016, it was estimated that 988,000 cases of syphilis among pregnant women occurred worldwide with 355,000 pregnancy-associated adverse outcomes (PAO) including near 109,000 cases of congenital syphilis, 61,000 neonatal deaths, and 41,000 cases of preterm delivery or low birth weight ${ }^{4}$. Reports from Brazil and the United States indicate a dramatic increase in the last decade of syphilis rates in pregnant women, congenital syphilis, infant mortality, abortions and stillbirths associated with Treponema pallidum ${ }^{5-7}$. This report communicates the epidemiological changes observed in southern Chile on syphilis along with its clinical features and outcomes in mothers and offspring.

\section{Patients and Methods}

\section{Study design}

Retrospective descriptive study using reported syphilis cases among pregnant women in the Los Ríos Region between years 2011 and 2019. This region is located in southern Chile and has an estimated population of 400,000 inhabitants who are mostly $(80 \%)$ cared for by the public healthcare insurance system in a network of primary care centers and public hospitals with a single referral center for high-risk obstetric pathology. Patients are referred to this center for evaluation and follow-up. For this study we included patients with a VDRL test reactive to any titer confirmed by a T. pallidum microhemaagglutination (MHA$\mathrm{TP}$ ) reactive test or cases with VDRL titer $\geq 1$ : 8 in absence of autoimmune diseases ${ }^{8,9}$. Cases with a history of previously treated syphilis with minimal non-treponemal reactive VDRL serology (undiluted or weakly reactive) were excluded. All VDRL and MHA-TP studies were carried out in the laboratory of the reference hospital.

Information was retrieved from clinical files of mothers and newborns. Variables of interest 
included mother's age, residence district, initiation of sexual activity, number of sexual partners in the last year, use of illicit drugs, gestational age at diagnosis, treatment received and opportunity (relation of the last dose with the time of delivery), serological evolution, and pregnancy outcome. Syphilis events in the mother were classified according to the CDC criteria ${ }^{8}$ in early syphilis, secondary syphilis, early latent syphilis, and latent syphilis. In the case of neonates, cases were classified as early CS, possible CS or unlikely $\mathrm{CS}^{8}$. Percentage of PAO linked to syphilis was also calculated according to definitions previously used in the literature (abortions, stillbirths, premature births, newborns weighing $<2500 \mathrm{~g}$, congenital syphilis, neonatal asphyxia or neonatal death $)^{4,10,11}$. This work includes two previously published case reports ${ }^{12,13}$. Re-infection cases were identified with a fourfold increase in titers (2 dilutions).

\section{Epidemiological changes}

Epidemiological data on syphilis from the Los Ríos Region and the country were rescued from official sources and from the Epidemiology Unit of the Regional reference hospital. Rates were calculated for the global population and for infected pregnant women.

\section{Statistic analysis}

Results associated with quantitative variables are presented as median with interquartile range (IQR), and categorical variables as percentages. Rate trends were analyzed by Spearman's correlation coefficient. Differences between VDRL titers according to the stages of infection were analyzed using the non-parametric Mann-Whitney test and Fisher exact test.

\section{Ethical issues}

This study was approved by the Comité de Ética Científica del Servicio de Salud de Valdivia.

\section{Results}

\section{Epidemiological changes}

National syphilis rates for both sexes increased from year 2016 with a parallel and significant increase in regional rates (Spearman coefficient + $0.88, \mathrm{p}<0.05$, Figure 1). Rates of syphilis among pregnant women attended in the regional refer- ence center also showed an increasing trend ( 0.4 to 7.2 per 1,000 live births between years 2013-2019).

\section{Syphilis among pregnant women attended in the public healthcare system}

Twenty nine cases of pregnant patients with syphilis attended in the public healthcare system were identified between years 2011 and 2019 . Median age was 28 years (IQR 23-32 years). Seven patients had history of abortion $(24.1 \%)$ and one of stillbirth (3.4\%). Parity was variable (none in $31 \%$, one in $37.9 \%$, two in $17.2 \%$, three in $10.3 \%$ and four in $3.4 \%)$. Alcohol consumption was reported in 5 mothers $(17.2 \%)$ and illicit drugs in the same number $(17.2 \%$, cocaine base paste in 4 out of 5 cases, and marijuana in the remaining case). Patients lived in 9 out of 12 regional districts and their educational level varied between elementary $(27.6 \%)$, high-school $(58.6 \%)$ and university studies $(13.8 \%)$. Four patients $(13.8 \%)$ had history of previous sexually transmitted diseases (STD: syphilis, genital warts and 2 cases of vaginal trichomoniasis, respectively). No cases of co-infection by HIV or hepatitis B virus were detected. Median number of sexual partners was 1 (range 1 to 4 ). Onset of sexual activity was reported in 15 cases (median 17 years; IQR 15 to 18 ; range 13 to 20 years). In 7 cases it was initiated at $\leq 16$ years of age $(46.7 \%$ of the group with data).

\section{Gestational age, infection stage, VDRL titers and treatment}

Median gestational age at the time of diagnosis was 24 weeks (range 8 to 41 weeks; IQR 17-33 weeks). In 7 cases diagnosis occurred at time of delivery $(24.1 \%)$, and the cumulative percentage diagnosed at third trimester or at time of delivery was $48.3 \%(\mathrm{n}=14)$. T. pallidum infection covered different stages, including primary syphilis (3.4\%), secondary syphilis $(13.8 \%)$, early latent syphilis (24.1\%), and latent syphilis (58.6\%). (Table 1$)$.

A total of 26 patients (86.9\%) were confirmed by a reactive MHA-TP test and the remaining 3 cases were associated with 1:16 VDRL titers and no evidence of associated autoimmune conditions. Table 2 shows VDRL titers highlighting that 31\% presented low titers $(\leq 1: 2)$ or a weak or doubtful reactive test.

VDRL titers were significantly higher among those cases with secondary syphilis compared to latent syphilis (Figure 2). All cases with a second- 


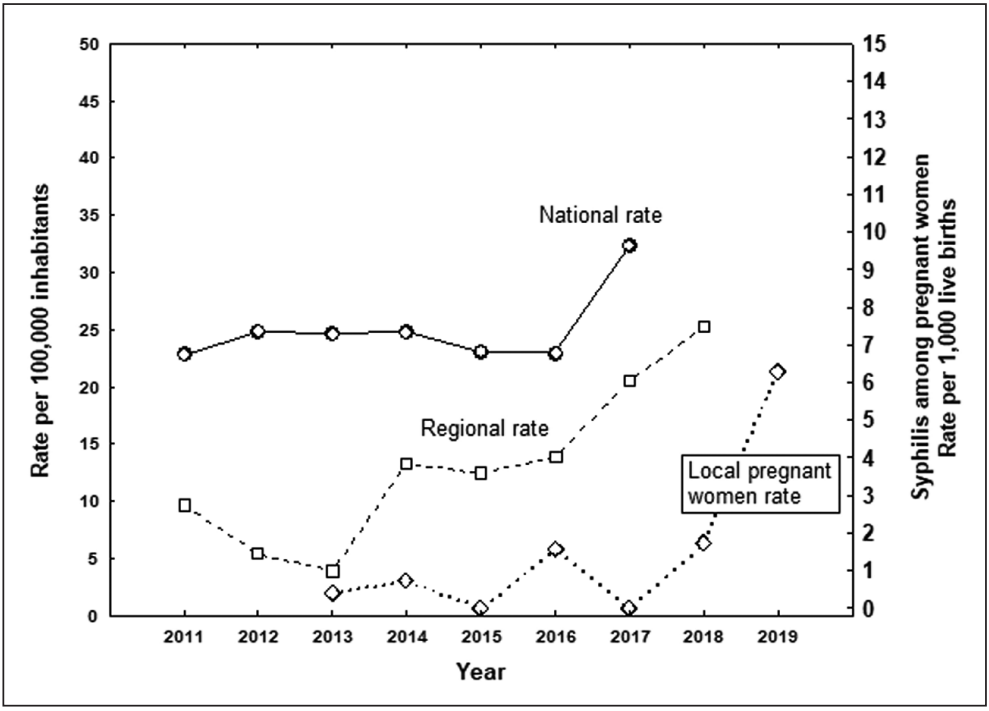

Figure 1. National and regional syphilis rate per 100,000 inhabitants (all stages, both sexes, left axis). A significant trend was detected for regional rates regional rates (Spearman coefficient +0.88 , $p<0.05)$. An increasing trend of syphilis rates was observed among pregnant women attended at the regional reference (right axis). Regional data for year 2019 and national data for years 2018-2019 was not available from official sources.
Table 1. Stage of infection among 29 pregnant women with syphilis, Región de Los Ríos, Chile 2011-2019.

\begin{tabular}{|lcc|}
\hline Stage & Frequency & Percentage \\
\hline Primary syphilis & 1 & $3.4 \%$ \\
Secondary syphilis & 4 & $13.8 \%$ \\
Early latent syphilis & 7 & $24.1 \%$ \\
Latent syphilis & 17 & $58.6 \%$ \\
Total & 29 & $100 \%$ \\
\hline
\end{tabular}

ary stage had titers 1: 8 to 1:16, significantly higher than the values observed in latent syphilis (median $1: 4$; range doubtful reactive to $1: 16$ ). Only cases belonging to latent syphilis were associated with titers $<1: 2$ ( $\mathrm{p}=0.028$ by two- sided Fisher test; Figure 2).

\section{Treatment}

Except for one case, all patients were treated with benzathine penicillin $G$ for 2 or 3 weekly doses. The exception (3.4\% of the series) corresponds to a previously reported case that received 2 courses of erythromycin therapy due to

Table 2. VDRL titers at diagnosis among 29 pregnant women with syphilis, 2011-2019, Región de Los Ríos, Chile

\begin{tabular}{|lccc|}
\hline Titer & Frequency & Percentage & Cumulative percentage \\
\hline Doubtful & 1 & $3.4 \%$ & $3.4 \%$ \\
Weakly reactive & 4 & $13.8 \%$ & $17.2 \%$ \\
\hline Reactive (undiluted) & 1 & $3.4 \%$ & $20.7 \%$ \\
$1: 2$ & 3 & $10.3 \%$ & $31.0 \%$ \\
$1: 4$ & 5 & $17.2 \%$ & $48.3 \%$ \\
$1: 8$ & 9 & $31.0 \%$ & $79.3 \%$ \\
$1: 16$ & 6 & $20.7 \%$ & $100 \%$ \\
\hline Total & 29 & $100 \%$ & $100 \%$ \\
\hline
\end{tabular}


suspicion of penicillin allergy. The treatment was later changed to penicillin after a desensitization protocol. Another patient with an immediate-type beta-lactam allergy was also desensitized totalizing $6.9 \%$ of the series. Timing of treatment was inadequate ( $<1$ month before delivery or postpartum) in 10 cases $(34.5 \%)$, including the 7 cases already mentioned in which the diagnosis was made at delivery (24.1\%).

Serological follow-up was available in 19 patients $(65.5 \%)$ and 14 out of them $(73.7 \%)$ showed a decreasing trend in VDRL titers ( $\geq$ one dilution) being significant in 10 ( $\geq 2$ dilutions, $52.6 \%$ of the subgroup). However, in 2 cases (6.9\% of the total group) a re-infection was documented due to a twofold dilution increase. As commented, titers also increased in a patient treated with macrolides (Figure 3).

\section{Pregnancy outcomes and evaluation of congenital syphilis}

In this series, 2 patients (6.9\%) evolved with spontaneous abortion, 8 with premature delivery $(27.6 \%)$ and the rest with full-term delivery
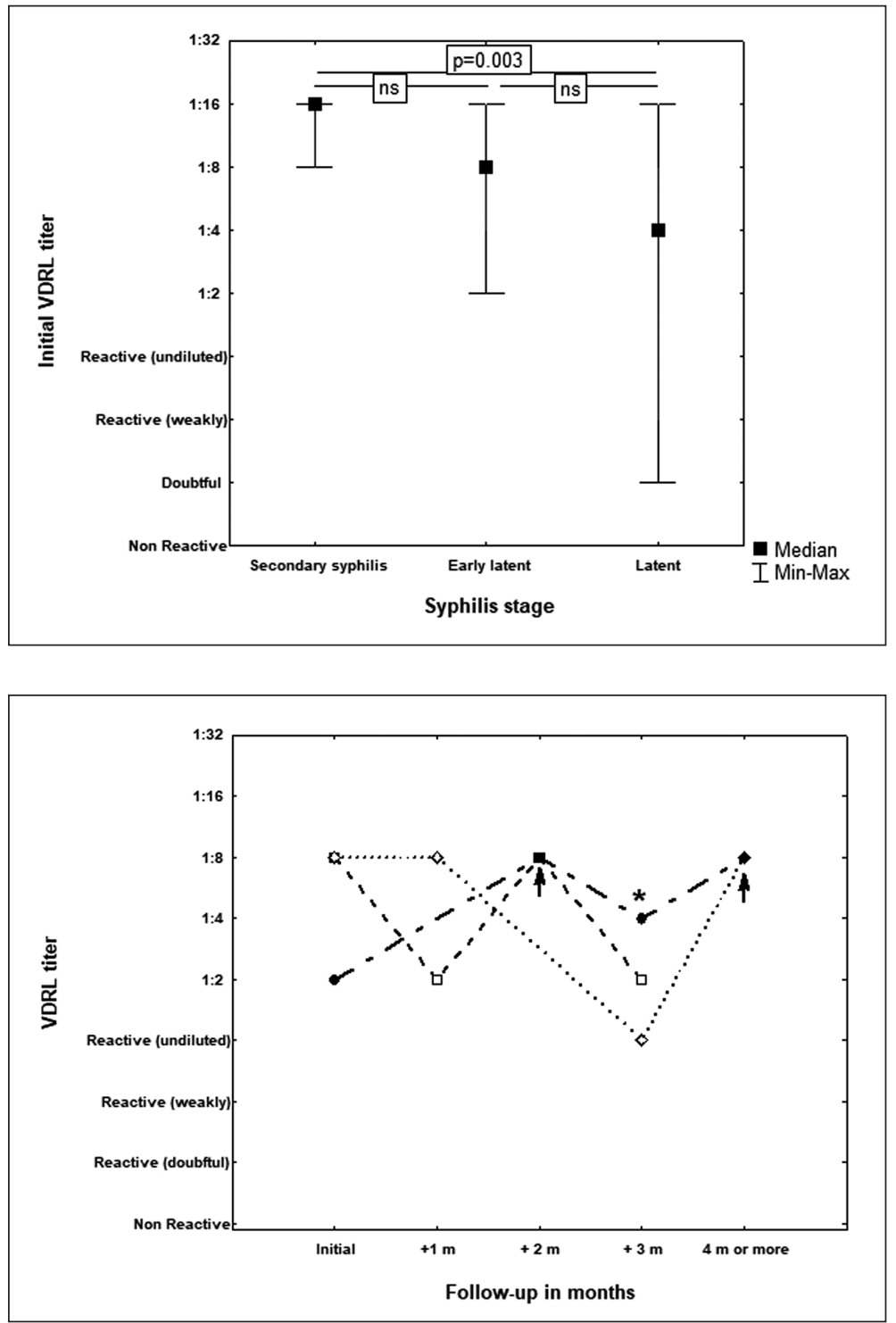

Figure 2. VDRL titers among 29 pregnant women with syphilis at different stages at diagnosis, 2011-2019, Región de Los Ríos, Chile. Comparisons were made using a non-parametric test (Mann-Whitney test), ns: non significant.
Figure 3. Serological follow-up in 2 cases of syphilis re-infection (arrows indicate time when re-infection was diagnosed) and in 1 case treated with macrolides (asterix). 
$(\mathrm{n}=19 ; 65.5 \%)$. The route of delivery was vaginal in 19 cases $(65.5 \%$, including 2 cases of abortion) or by caesarean section $(\mathrm{n}=10 ; 34.5 \%)$ (Table 3$)$. The overall rate of PAO was $34.5 \%(\mathrm{n}=10)$, (Table 3 ) including 2 cases of spontaneous abortion, 6 premature births (without CS) and 2 cases of CS.

The 2 newborns with CS (6.9\%) (Tables 3 and 4) had premature births. One case presented hydrops fetalis, mucocutaneous lesions, hepatomegaly, pneumonia, proteinuria, thrombocytopenia, and necrotizing funisitis in placental histology. Initial VDRL titers in this newborn were higher than those observed in her mother (1:16 vs. $1: 8$, respectively) and later on increased further (1:64).

Table 3. Pregnancy-adverse outcomes distribution among 29 pregnant women with syphilis, 2011-2019, Región de Los Ríos, Chile

\begin{tabular}{|lcc|}
\hline Outcome & $\begin{array}{c}\text { Fre- } \\
\text { quency }\end{array}$ & $\begin{array}{c}\text { Percent- } \\
\text { age }\end{array}$ \\
With fetal loss & 2 & $6.9 \%$ \\
Spontaneous abortion & & \\
Live births & 6 & $20.7 \%$ \\
Premature without CS* & 2 & $6.9 \%$ \\
Congenital syphilis** & 10 & $34.5 \%$ \\
Total with an adverse outcome & 10 \\
\hline
\end{tabular}

${ }^{*}$ CS: congenital syphilis; both CS cases had premature births.
The other case presented neonatal hepatitis with jaundice of direct bilirrubin predominance. VDRL titers were similar between mother and the newborn (1:8). Both women had latent syphilis (treated with macrolides and untreated, respectively).

Besides 2 newborns with early CS, evaluation of vertical transmission indicated other 7 patients $(24.1 \%)$ (Table 4 ) with possible CS either by lack of treatment during pregnancy, re-infection without treatment, or inappropriate opportunity for treatment before delivery. In these cases, there was no evidence on physical examination nor in laboratory exams of early CS. In all of them, newborn's VDRL titers were equal to or lower than those of their mothers. Finally, in more than half of the 29 pregnancies $(n=17 ; 58.6 \%)$ the existence of CS among newborns was judged to be unlikely due to the appropriateness of the treatment, serological response of the mother, and the absence of clinical elements in the newborn. One case could not be analyzed due to the absence of clinical and laboratory data on the newborn (3.4\%).

All neonates with possible syphilis were evaluated with a lumbar puncture for CSF analysis, eye funduscopic examination and long bone radiographies without detecting abnormalities. These 7 patients, along with those with congenital syphilis received intravenous penicillin $\mathrm{G}$ sodium treatment. Patients with CS made a full recovery after treatment.

Table 4. Evaluation of congenital syphilis among 29 pregnant women attended at the public healthcare system, Región de Los Ríos, Chile; 2011-2019

\begin{tabular}{|lll|}
\hline Outcome & $\mathbf{n ~ ( \% )}$ & Comments \\
$\begin{array}{l}\text { Early congenital syphilis } \\
\text { Altered physical examination }\end{array}$ & $2(6,9)$ & $\begin{array}{l}\text { Both treated with intravenous penicillin G and discharged } \\
\text { alive }\end{array}$ \\
$\begin{array}{l}\text { Possible congenital syphilis } \\
\text { Lack of treatment during pregnancy, } \\
\text { re-infection without treatment, or } \\
\text { inappropriate opportunity for treatment } \\
\text { before delivery (< 1 month) }\end{array}$ & $7(24,1 \%)$ & $\begin{array}{l}\text { All treated with intravenous penicillin G. } \\
\text { All evaluated by CSF analysis, long bone } x \text {-rays and eye } \\
\text { funduscopic examination. None altered. }\end{array}$ \\
$\begin{array}{l}\text { Congenital syphilis unlikely } \\
\text { Appropriateness of treatment, serological } \\
\text { response of the mother, and absence of } \\
\text { clinical elements in the newborn }\end{array}$ & $17(58,6 \%)$ & \\
Abortion & $2(6,9 \%)$ & Not included in CS analysis. \\
Without information & $1(3,4 \%)$ & Mother adequately treated \\
\hline $\begin{array}{l}\text { Total } \\
2(100 \%)\end{array}$ & \\
\hline
\end{tabular}




\section{Discussion}

Syphilis rate has increased in the Chilean population since 2016 doubling previous rates in a short period of time. This increase is also reflected in regional rates and among pregnant women with potential fetal and/or PAO. This resurgence is accompanied with the appearance of a new risk group that is added to the known classical groups (MSM, sex workers, transgender women $)^{14}$. Chile appears to escort other developed or developing countries with the same epidemiological change that is reversing recent favorable worldwide trends ${ }^{4-6}$. Darkening this picture HIV/AIDS and gonorrhoea rates have also increased in male and female populations in our country between years 2013 and 2017 ( 4.8 to 5.1 and 2.3 to 4.7 per 100,000 inhabitants for female gender, respectively) underlining a complex scenario associated to a weakened STD prevention program ${ }^{15,16}$. Investment in public prevention campaign for STD has remained static, of low magnitude $(<1$ million dollars/year) and encompassing only few months every year ${ }^{17}$. Besides, the incorporation of sex education programs in secondary education has been slow and has not been able to increase the use of male condoms or reduce the rate of gonorrhea and HIV in the adolescent population, facts that can influence STD among young pregnant women ${ }^{18}$.

This increase affects practically the entire region, involves mothers with different educational levels and is only partially associated with a previous history of STD, drug abuse, early initiation of sexual activity, previous abortions or late diagnosis or untimely treatment, all known risk factors for syphilis during pregnancy. It has been described that the risk of syphilis infection in pregnant women is associated with unmarried women, low educational level, poverty, multiple sexual partners, drug addiction in the patient or in her sexual partner, previous abortions or STD, absence of preventive counseling, sexual activity initiation $\leq 16$ years and a low number of prenatal controls $^{19-21}$.

Syphilis in pregnancy is not equivalent to CS since frequent prenatal check-ups, active search for syphilis during pregnancy, and timely treatment of detected cases, significantly prevent the risk of fetal, CS or PAO associated with this infection $^{10}$. On the contrary, the risk of CS increases during early stages of syphilis (primary chancre, secondary or early latent syphilis) due to an associated spirochetemia with the menace of vertical transmission. The risk also increase for untreated syphilis or untimely treated before delivery $(<1$ month), delayed diagnosis, low number of prenatal controls, non-treponemal high titer test results, a drug-addicted couple and / or patient's rurality ${ }^{10,11,20,22}$.

Unfortunately, damage associated with syphilis in pregnancy is broader than CS, with other PAO, which in global terms quadruple the frequency of $\mathrm{CS}^{4,10,11}$. The burden of disease generated by PAO, including CS is relevant both in terms of human suffering as well as for its potential sequels, hospitalizations and healthcare and social expenses.

Since 2006, Chile is performing 3 syphilis detection tests during pregnancy, and in 2016 an additional test was added at the time of delivery ${ }^{23}$. This strategy has improved detection coverage and treatment timeliness, but is limited in cases of reduced prenatal check-ups. In our series, about $25 \%$ of the cases were diagnosed at the time of delivery, approximately a third received inappropriate treatment, and a similar percentage was associated with PAO.

As described previously, VDRL titers show a wide distribution trough syphilis stages making difficult to recognize them trough serological results $^{24}$. More relevant was its use for monitoring treatment response and to identify re-infection as shown in our series.

Our work has limitations. It only covered one region of Chile, and results cannot be extrapolated to assess the real magnitude of the reemergence of syphilis in pregnant women throughout the country. On the other hand, 3 cases in our series did not have confirmation by treponemal tests, however observed titers (VDRL $\geq 1: 8$ ) were far from titers reported as false positive results during pregnancy 9 . Our study did not include an appropriate serological follow-up of newborns diagnosed with possible CS perhaps to difficulties in achieving attendance at postpartum controls, medical attention by inadequately trained professionals or by mobility restrictions imposed by the COVID-19 pandemic during year 2020, a period in which most of the infants were scheduled for follow-up.

A high fraction of newborns exposed to $T$. pallidum (near 25\%) did not receive antibiotic treatment or they did in a delayed timeframe 
favoring vertical transmission, and as such, they were classified as having possible CS. This condition is hard to dissect, because they do not express clinical manifestations and no abnormalities are detected in radiological, ophthalmological or CSF studies. Furthermore, positive non-treponemal tests in their blood are difficult to interpret because of the maternal transfer of IgG antibodies that contributes to a positive VDRL test. Given the risk of an infection that could be evident in the coming weeks or months, these patients are treated with penicillin empirically, being unethical to only observe these infants without treatment.

Desensitization to penicillin was necessary in at least 2 cases due to immediate-type allergy to beta-lactams. Penicillin is the only effective antimicrobial to prevent vertical transmission in pregnant women with syphilis and therefore recommendations from developed countries include desensitization to this compound when an immediate-type allergy is detected ${ }^{8,25}$. Other options are not appropriate due to contraindication during pregnancy (doxycycline) or failure to prevent vertical transmission as observed with macrolides (due to limited placental trespassing), which is further complicated by high resistance rates ${ }^{13,26-34}$. Desensitization to PNC is possible in developing countries for the management of pregnant women with syphilis ${ }^{12,35}$. Nonetheless, emergence of macrolides resistance creates a huge pressure to expand penicillin desensitization protocols in developing countries among pregnant women with syphilis and immediate-type allergy to beta-lactams.

\section{References}

1. Ghanem KG, Ram S, Rice PA. The Modern epidemic of syphilis. N Engl J Med. 2020; 382 (9): 845-54.

2. Spiteri G, Unemo M, Mårdh O, Amato-Gauci AJ. The resurgence of syphilis in high-income countries in the 2000s: a focus on Europe. Epidemiol Infect. 2019; 147: e143.

3. Cooper JM, Sánchez PJ. Congenital syphilis. Semin Perinatol. 2018; 42 (3): 176-84.

4. Korenromp EL, Rowley J, Alonso M, Mello MB, Wijesooriya NS, Mahiané SG, et al. Global burden of maternal and congenital syphilis and associated adverse birth outcomes-Estimates for 2016 and progress since 2012. PLoS One 2019; 14 (2): e0211720.
5. Bezerra MLMB, Fernandes FECV, de Oliveira Nunes JP, de Araújo Baltar SLSM, Randau KP. Congenital syphilis as a measure of maternal and child healthcare, Brazil. Emerg Infect Dis. 2019; 25 (8): 1469-76.

6. Trivedi S, Williams C, Torrone E, Kidd S. National trends and reported risk factors among pregnant women with syphilis in the United States, 2012-2016. Obstet Gynecol. 2019;133 (1): 27-32.

7. Slutsker JS, Hennessy RR, Schillinger JA. Factors contributing to congenital syphilis cases - New York City, 2010-2016. MMWR Morb Mortal Wkly Rep. 2018; 67 (39): 1088-93.

8. Centers for Disease Control and Prevention. Sexually transmitted diseases treatment guidelines, 2015. MMWR 2015; 64 (RR3): 1-137.

9. Lobos P, Ortega R, Vera C, Poblete P, Saéz C. [Prevalence of false seropositivity for syphilis in a population of pregnant women]. Rev Med Chile 1992; 120 (10): 1121-6.

10. Qin JB, Feng TJ, Yang TB, Hong FC, Lan LN, Zhang $\mathrm{CL}$, et al. Risk factors for congenital syphilis and adverse pregnancy outcomes in offspring of women with syphilis in Shenzhen, China: a prospective nested case-control study. Sex Transm Dis. 2014; 41 (1): 13-23.

11. Zhang X, Yu Y, Yang H, Xu H, Vermund SH, Liu K. Surveillance of maternal syphilis in China: Pregnancy outcomes and determinants of congenital syphilis. Med Sci Monit. 2018; 24: 7727-35.

12. Fica A, Muñoz D, Rojas T, Sanzana C, Muñoz C. [Penicillin desensitization in allergic pregnant women with syphilis. Report of two cases]. Rev Med Chile 2020; 148: 344-8.

13. Fica A, Tager M, Muñoz D, Guerra F, Vargas J. [Congenital syphilis after maternal macrolide therapy in a presumed allergic patient. Time to change the Chilean governmental normative. Case Report]. Rev Med Chile 2019; 147: 944-6.

14. Kojima N, Klausner JD. An update on the global epidemiology of syphilis. Curr Epidemiol Rep. 2018; 5 (1): 24-38.

15. Cáceres K. Informe: situación epidemiológica de las infecciones de transmisión sexual en Chile, 2017. Rev Chilena Infectol. 2019; 36 (2): 221-33.

16. Stuardo V. La prevención olvidada, la reemergencia del VIH en Chile. Rev Chilena Infectol. 2017; 34 (4): 41920.

17. Aguayo I. Gasto en campañas de prevención del VIH/ SIDA en Chile para el período 2010-2019. Available at: http://www.sidastudi.org/resources/inmagic-img/ DD57236.pdf Visited 05.09.2019.

18. Castro-Sandoval G, Carrasco-Portiño M, Solar-Bustos 
F, Catrien-Carillo M, Garcés-González C, Marticorena-Guajardo C. Impacto de las políticas de educación sexual en la salud sexual y reproductiva adolescente en el sur de Chile, período 2010-2017. Rev Chil Obstet Ginecol. 2019; 84 (1): 28-40.

19. Zhou H, Chen XS, Hong FC, Pan P, Yang F, Cai YM, et al. Risk factors for syphilis infection among pregnant women: results of a case-control study in Shenzhen, China. Sex Transm Infect. 2007; 83 (6): 476-80.

20. Casal C, Araújo Eda C, Corvelo TC. Risk factors and pregnancy outcomes in women with syphilis diagnosed using a molecular approach. Sex Transm Infect. 2013; 89 (3): 257-61.

21. Macêdo VC, Lira PIC, Frias PG, Romaguera LMD, Caires SFF, Ximenes RAA. Risk factors for syphilis in women: case-control study. Rev Saude Publica 2017; 51: 78.

22. Mobley JA, McKeown RE, Jackson KL, Sy F, Parham JS, Brenner ER. Risk factors for congenital syphilis in infants of women with syphilis in South Carolina. Am J Public Health. 1998; 88 (4): 597-602.

23. Ministerio de Salud, Chile. Norma de profilaxis, diagnóstico y tratamiento de las infecciones de transmisión sexual (ITS). 2016. Available at: http://www. repositoriodigital.minsal.cl/bitstream/handle/2015/909/ Norma $\% 20 \mathrm{de} \% 20$ Profilaxis\%20Diagnoostico $\% 20 \mathrm{y} \% 20$ Tratamiento $\% 20 \mathrm{de} \% 20 \mathrm{las} \% 20$ Infecciones $\% 20 \mathrm{de} \% 20$ Transmision $\% 20$ Sexual.pdf? sequence $=1$ \&isAllowed $=\mathrm{y}$ Visited 19.08.2020.

24. Talwar S, Tutakne NA, Tiwari VD. VDRL titers in early syphilis before and after treatment. Genitourin Med. 1992; 68: 120-2.

25. Janier M, Hegyi V, Dupin N, Unemo M, Tiplica GS, Potočnik M, et al. 2014 European guideline on the management of syphilis. J Eur Acad Dermatol Venereol. 2014; 28 (12): 1581-93.

26. Holder WR, Knox JM. Syphilis in pregnancy. Med Clin North Am. 1972; 56 (5): 1151-605.

27. Fenton LJ, Light IJ. Congenital syphilis after maternal treatment with erythromycin. Obstet Gynecol. 1976; 47 (4): 492-4.
28. Zhou P, Qian Y, Xu J, Gu Z, Liao K. Occurrence of Congenital Syphilis After Maternal Treatment With Azithromycin During Pregnancy. Sex Trans Dis. 2007; 34 (7): 472-4.

29. Eltabbakh GH, Elejalde BR, Broekhuizen FF. Primary syphilis and nonimmune fetal hydrops in a penicillin-allergic woman. A case report. J Reprod Med 1994; 39 (5): 412-4.

30. Ricci JM, Fojaco RM, O'Sullivan MJ. Congenital syphilis: the University of Miami/Jackson Memorial Medical Center experience, 1986-1988. Obstet Gynecol. 1989; 74 (5): 687-93.

31. Hashisaki P, Wertzberger GG, Conrad GL, Nichols CR. Erythromycin failure in the treatment of syphilis in a pregnant woman. Sex Transm Dis. 1983; 10 (1): 36-8.

32. Grimes M, Sahi SK, Godornes BC, Tantalo LC, Roberts $\mathrm{N}$, Bostick D, et al. Two mutations associated with macrolide resistance in Treponema pallidum: increasing prevalence and correlation with molecular strain type in Seattle, Washington. Sex Transm Dis. 2012; 39 (12): 954-8.

33. Muldoon EG, Walsh A, Crowley B, Mulcahy F. Treponema pallidum azithromycin resistance in Dublin, Ireland. Sex Transm Dis. 2012; 39 (10): 784-6.

34. Beale MA, Marks M, Sahi SK, Tantalo LC, Nori AV, French P, et al. Genomic epidemiology of syphilis reveals independent emergence of macrolide resistance across multiple circulating lineages. Nat Commun. 2019; 10 (1): 3255.

35. Giacani L, Ciccarese G, Puga-Salazar C, Dal Conte I, Colli L, Cusini M, et al. Enhanced Molecular Typing of Treponema pallidum subspecies pallidum strains from 4 Italian hospitals shows geographical differences in strain type heterogeneity, widespread resistance to macrolides, and lack of mutations associated with doxycycline resistance. Sex Transm Dis. 2018; 45 (4): 237-42.

36. Dallé J, Ramos MC, Jimenez MF, Escobar FG, Antonello VS. Oral desensitization to penicillin for the treatment of pregnat women with syphilis: A successful program. Rev Bras Ginecol Obstet. 2018; 40 (1): 43-6. 